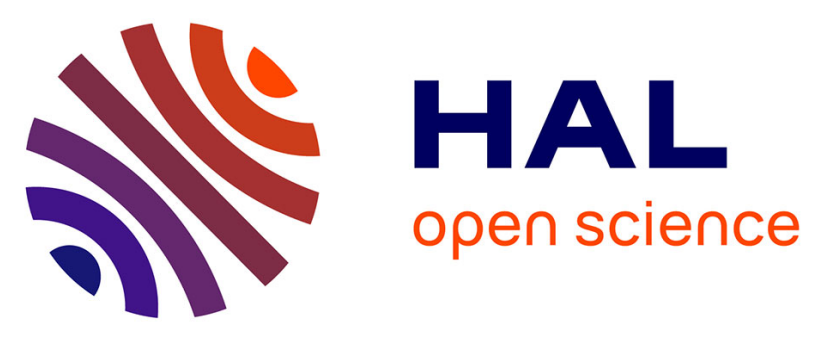

\title{
Liver transcriptome modifications by nutrient restriction in early lactation Holstein cows challenged with intramammary lipopolysaccharide
}

Karol Pawlowski, Christine Leroux, Yannick Faulconnier, Céline Boby, Anne de La Foye, Denys Durand, José Pires

\section{To cite this version:}

Karol Pawlowski, Christine Leroux, Yannick Faulconnier, Céline Boby, Anne de La Foye, et al.. Liver transcriptome modifications by nutrient restriction in early lactation Holstein cows challenged with intramammary lipopolysaccharide. 2016 JAM Joint Annual Meeting, Jul 2016, Salt Lake City, United States. American Dairy science Association - American Society of Animal Science, 2016, 2016 JAM, Joint Annual Meeting " Animals and Science: Big Solutions for Grand Challenges". hal-02743752

\section{HAL Id: hal-02743752 \\ https://hal.inrae.fr/hal-02743752}

Submitted on 3 Jun 2020

HAL is a multi-disciplinary open access archive for the deposit and dissemination of scientific research documents, whether they are published or not. The documents may come from teaching and research institutions in France or abroad, or from public or private research centers.
L'archive ouverte pluridisciplinaire HAL, est destinée au dépôt et à la diffusion de documents scientifiques de niveau recherche, publiés ou non, émanant des établissements d'enseignement et de recherche français ou étrangers, des laboratoires publics ou privés. 


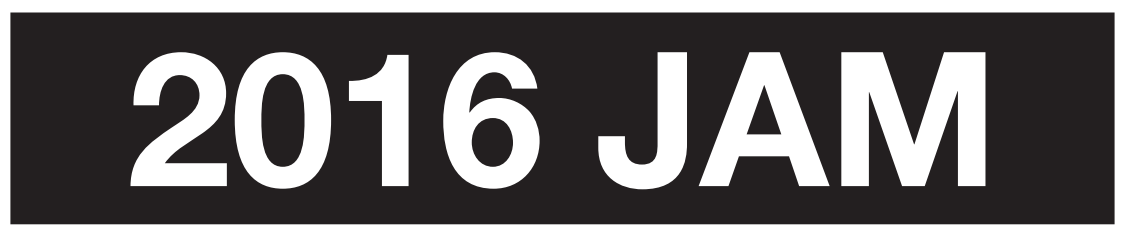

\title{
Joint Annual Meeting
}

\author{
July 19-23, 2016 \\ Salt Lake City, UT
}

American Society of Animal Science Journal of Animal Science Volume 94, E-Supplement 5

American Dairy Science Association ${ }^{\circledR}$ Journal of Dairy Science ${ }^{\circledR}$ Volume 99, E-Supplement 1 


\section{Predicting hyperketonemia prevalence in Jersey herds from milk composition and cow test-day information using multiple linear regression.} T. L. Chandler ${ }^{* 1}$, N. Zhang ${ }^{1,2}$, M. R. Skiba ${ }^{1}$, S. G. Moore ${ }^{3}$, M. O. Caldeira ${ }^{3}$, S. E. Poock ${ }^{3}$, G. R. Oetzel ${ }^{4}$, C. W. Wolfe ${ }^{5}$, R. H. Fourdraine ${ }^{6}$, and H. M. White ${ }^{1} .{ }^{1}$ Department of Dairy Science University of Wisconsin, Madison, ${ }^{2}$ Feed Research Institute Chinese Academy of Agricultural Sciences, Beijing, China, ${ }^{3}$ University of Missouri, Columbia, ${ }^{4}$ Department of Medical Sciences, School of Veterinary Medicine, University of Wisconsin, Madison, ${ }^{5}$ American Jersey Cattle Association, Reynoldsburg, $\mathrm{OH},{ }^{6} \mathrm{CRI}$ International Center for Biotechnology, Mount Horeb, WI.

Multiple linear regression models have been validated to predict hyperketonemia in Holstein herds; however, potential differences in milk composition and hyperketonemia prevalence warranted further sampling and distinct models for Jersey herds. The objective of this study was to validate the use of multiple linear regression models to predict $\beta$-hydroxybutyrate (BHBA) from milk composition and continuous testday variables in Jersey cows to serve as a diagnostic tool for determining herd-level ketosis prevalence. Blood samples were collected on the same day as milk sampling from 468 Jersey cows 5 to 20 DIM on six dairy farms. Serum BHBA concentration was quantified by colorimetric assay (Stanbio, Boerne, TX). Milk samples were analyzed for concentrations of milk BHBA, acetone, and fatty acid (FA) groups (saturated, unsaturated, trans, short, medium, and long chain FA) by fourier transform infrared (FTIR) spectrometry from MilkoScan FT+ (FOSS Analytical A/S, Hillerød, Denmark), in addition to standard milk analysis variables. Continuous test-day variables were exported from DairyComp305 (Valley Ag Software, Tulare, CA) records. Models were built in the REG procedure of SAS 9.4 (SAS Institute Inc., Cary, NC) using forward stepwise selection by excluding variables with a $P$-value $>0.15$ and using selection criterion of sequential sums of squares, error sums of squares, and Akaike's information criterion. Statistical parameters $\left(R^{2}\right.$, adjusted $R^{2}$, root mean square error) were calculated to evaluate model performance. Hyperketonemia, defined as a serum BHBA $\geq 1.2$ $\mathrm{mM}$, prevalence within the sample set was $20 \%$. Data interrogation justified development of separate models for primiparous and multiparous groups, as well as 5 to 11 and 12 to 20 DIM groups. Significant variables were BHBA, acetone, fat $\%$, protein $\%$, somatic cell count, FA groups, pervious days carried calf, age at calving, previous ME305 milk production, test-day DIM and milk production. Overall, model accuracies were $91 \%$ for multiparous cows 5 to 11 DIM $\left(R^{2}\right.$ $=0.85), 86 \%$ for multiparous cows 12 to $20 \operatorname{DIM}\left(R^{2}=0.64\right)$, $90 \%$ for primiparous cows 5 to $11 \mathrm{DIM}\left(R^{2}=0.64\right)$, and $90 \%$ for primiparous cows 12 to $20 \mathrm{DIM}\left(R^{2}=0.83\right)$. Collectively, models predicted animals with hyperketonemia at the $1.2 \mathrm{mM}$ threshold with $86 \%$ accuracy. Results suggest that modeling blood BHBA based on milk composition data and cow-test day information provides a practical tool for monitoring hyperketonemia prevalence in Jersey herds.

Key Words: ketosis, linear regression, Jersey

\section{Liver transcriptome modifications by nutrient restriction in early lactation Holstein cows challenged with intramammary lipopolysaccharide. K. Pawlowski ${ }^{1}$, C. Leroux ${ }^{1}$, Y. Faulconnier ${ }^{1}$, C. Boby ${ }^{2}$, A. de la Foye ${ }^{2}$, D. Durand ${ }^{1}$, and J. A. A. Pires ${ }^{*_{1}},{ }^{1} U M R 1213$ Herbivores, INRA, VetAgroSup, Saint-Genes- Champanelle, France, ${ }^{2}$ PFEM, INRA, Saint- Genes-Champanelle, France.}

The objective was to test effects of nutrient restriction on liver transcriptome $24 \mathrm{~h}$ after an intramammary lipopolysaccharide (LPS) challenge in early lactation cows. At $24 \pm 3 \mathrm{~d}$ in milk, multiparous cows were either allowed to continue ad libitum intake of a lactation diet (CON, $n=6)$, or the ration was diluted with barley straw ( $48 \% \mathrm{DM})$ for $4 \mathrm{~d}$ (RES, $n=6)$. On $\mathrm{d} 3$, one healthy rear mammary quarter was infused with 50 $\mu \mathrm{g}$ of LPS (E. coli 0111:B4). Blood and liver biopsies were collected on $\mathrm{d} 4$, corresponding to $24 \mathrm{~h}$ after LPS challenge. Liver transcriptome was analyzed with $44 \mathrm{~K}$ bovine microarrays (Agilent Technologies). Blood and transcriptomic data were analyzed using SAS mixed models and GeneSpring (moderated $t$ test with Westfall-Young correction, $P<0.05$ ), respectively, and data mining was performed using Panther and Pathway Studio software. Energy balance did not differ before diet change. By experimental design, energy intake was limited to 41 and $97 \pm 15 \%$ of $\mathrm{NE}_{\mathrm{L}}$ requirements in RES and CON, respectively (mean $\pm \mathrm{SD} ; P<0.001$ ). Plasma NEFA and BHBA were greater, and glucose was lower for RES compared with CON (1221 vs. $382 \mu \mathrm{M}, 2.67$ vs. $0.70 \mathrm{mM}, 56$ vs. $69 \mathrm{mg} / \mathrm{dL}$ respectively, $P \leq 0.05$, before biopsy), which is consistent with $4 \mathrm{~d}$ of nutrient deficit in REST. We detected 77 differently expressed genes (DEG) between CON and RES, with 29 down-regulated and 48 up-regulated in RES. Genes involved in fatty acid synthesis (ACAT2, FASN, SCD), lactate metabolism $(L D H C)$, and cortisol binding (SERPINA6) were down-regulated in RES, whereas those involved in fatty acid oxidation, detoxification, cholesterol synthesis, lipoprotein lipid secretion, and gluconeogenesis $(A C A D V L, C P T 1 A$, CPT1B, ANGPTL4, CYP4A11, HMGCSA, APOA1, APOA4, $G K, P C$, and $P C K 2$ ) were up-regulated in RES. Overall, DEG were in agreement with negative energy balance and plasma metabolite profile, and reflect a state intense lipomobilization, glucose deficit and ketogenesis in RES. Preliminary results suggest that nutrient restriction did not change liver expression of genes directly involved in immune function $24 \mathrm{~h}$ after 
an intramammary LPS challenge.

Key Words: inflammation, liver transcriptome, undernutrition

\section{Growth and transcriptional profile analysis following oral probiotic supplementation in dairy cows. M. Worku*, S. Adjei-Fremah, K. Ekwemalor, E. Asiamah, and H. Ismail, North Carolina Agricultural and Technical State University, Greensboro.}

The objective of this study was to assess the impact of probiotic administration on growth and global gene expression profile in dairy cow. Use of probiotic supplements is a nonchemical approach to promote animal health. Understanding the mechanism of action of probiotics in cows may aid in sustainable dairy production. Lactating Holstein-Friesian cows $(n=10)$ received daily oral doses $(50 \mathrm{ml})$ of a commercial probiotic FASTtrak microbial pack (Conklin Company, Kansas City, MO) (containing Lactobacillus acidophilus, Saccharomyces cerevisiae, Enterococcus faecium, Aspergillus oryza, and Bacillus subtilis) over a $60-\mathrm{d}$ period. Body weight was recorded weekly. Whole blood was collected at the beginning $(\mathrm{d} 0)$ and end of the study (d 60). Blood samples were analyzed for total and viable cell count, packed cell volume (PCV), white blood cell differential counts (WBC), and total protein concentration in plasma. Daily supplementation of probiotics had no effect on $\mathrm{BW}, \mathrm{PCV}$, and total protein concentration in plasma at the end of the study $(P>0.05)$. Percentage lymphocyte count increased $(P<0.05)$, and percentage neutrophil count $(P<$ $0.05)$ decreased in probiotic-treated animals. Gene expression analysis identified 10,859 differentially expressed genes, 1168 up-regulated and 9691 down-regulated genes respectively following probiotic administration. Pathway analysis identified 87 bovine pathways impacted by probiotic treatment. These pathways included the Toll-like receptor signaling pathway, inflammation response and Wnt signaling pathways. Oral administration of probiotic to dairy cows has a systemic effect on global gene expression, including genes involved in immunity and homeostasis (Wnt). The results of this study show that the utilization of probiotics in animal agriculture impacts genes important to dairy cow health and production. Further definition of the interaction between the pathways involved may aid in the design of the most effective probiotics for optimum dairy production and health.

Key Words: dairy cows, innate immunity, microarray, probiotic
0131 Mammary gland transcriptome and proteome modifications by nutrient restriction in early lactation Holstein cows challenged with intramammary lipopolysaccharide.

K. Pawlowski ${ }^{1}$, C. Chambon ${ }^{2}$, C. Boby ${ }^{2}$, A. de la Foye ${ }^{2}$, Y. Faulconnier ${ }^{1}$, J. A. A. Pires ${ }^{* 1}$, C. Leroux ${ }^{1},{ }^{1}$ UMR1213 Herbivores, INRA, VetAgroSup, Saint-Genes-Champanelle, France, ${ }^{2}$ PFEM, INRA, Saint-Genes-Champanelle, France.

The objective was to evaluate the effect of nutrient restriction and intramammary lipopolysaccharide (LPS) challenge on mammary gland (MG) gene expression in early lactation cows. At $24 \pm 3 \mathrm{~d}$ in milk, multiparous cows were either allowed to continue ad libitum intake of a lactation diet $(\mathrm{CON}$, $n=6)$, or the ration was diluted with barley straw (48\% DM) for $4 \mathrm{~d}$ (RES, $n=6$ ). On d 3, one healthy rear mammary quarter was infused with $50 \mu \mathrm{g}$ of LPS. Mammary biopsies were performed $24 \mathrm{~h}$ after LPS challenge. RNA and proteins analyzed using bovine $44 \mathrm{~K}$ microarrays (Agilent Technologies) and micro-LC-MS/MS, respectively. Transcriptomic data were analyzed using GeneSpring (moderated- $t$ test with Westfall-Young correction, $P<0.05)$. Proteins were analyzed with Progenesis LC-MS software v.4.1 (Nonlinear Dynamics). Production and energy balance did not differ before diet change. Negative energy balance was aggravated in RES (41 vs. $97 \pm 15 \%$ of requirements, mean $\pm \mathrm{SD} ; P<0.001)$. A total of 87 differentially expressed genes (DEG) were highlighted through the comparison of RES vs. CON group. Among the 33 DEG identified in the transcriptomic analyses, 11 and 22 were down- and up-regulated by restriction, respectively. Among the up-regulated DEG, there were PDK4 and CPT1A which are involved in the regulation of fatty acid, ketone, and glucose metabolism. CPT1A is the key enzyme in the carnitine dependent fatty acid transport, promoting fatty acid oxidation. Genes involved in immune response such as $P G$ LYRP3 and TRIB2 were up-regulated, suggesting a higher inflammatory response in RES than CON. Proteomic analysis identified 54 proteins with 14 up- and 40 down-regulated in RES cows. Up-regulated proteins were mostly involved in gene expression mechanisms such as translation, RNA splicing and cellular protein modification. The down-regulated proteins (e.g., EIF3H, RS27A, RS15) take part in protein metabolism. This is coherent with transcriptomic results, namely the down-regulation of $R P L 37 A$, a component of ribosomal complex, which catalyzes protein synthesis and may partially explain the lower milk protein yield in RES (834 vs. $1163 \mathrm{~g} / \mathrm{d}$; $P=0.02$ ). Proteins involved in antigen processing and presentation were down-regulated in RES compared with CON, suggesting an impaired ability to counteract inflammation in RES MG. Preliminary transcriptomics and proteomics analyses show that undernutrition may influence the MG response 